\title{
The California Law of Malpractice of Physicians, Surgeons, and Dentists
}

\author{
John Harold Swan*
}

\begin{abstract}
A SURPRISING number of malpractice cases have in recent years come before the California district courts of appeal and the Supreme Court. It is the purpose of this discussion to indicate the significance of these cases as they develop what may be called the California law on liability, pleading and proof in malpractice cases. ${ }^{1}$
\end{abstract}

I.

\section{THE RELATIONSHIP OF PHYSTCIAN AND PATIENT}

a. Creation of the Relationship. A physician is not obliged to accept a patient for treatinent, nor has a patient any duty to accept treatment. Acceptance by the patient of medical service, however, creates the relationship of physician and patient. The relationship does not depend upon an express contract. ${ }^{2}$ Indeed, the patient may be legally unable to contract, e. g. an unconscious person, or he may receive medical service or treatment as a result of a contract between

*Associate Editor, California Law Review. A.B., University of California at Los Angeles, 1925; M.A., University of California, 1927. Member, California State Senate, 1941-1945, from Nineteenth District.

1 There is no specific statutory law on malpractice in California. Rclevant decisions from other jurisdictions are higbly persuasive, and the Caliiornia cases abound in citations of holdings of courts of other states. California cases only are cited as authority in the present discussion. See: 20 CAL. JUR. 1073-1082, 18 MCK. Dig. 592-608; 41 AM. JUR. 192-253.

2 The case of McNamara v. Emmons (1939) 36 Cal. App. (2d) 199, 97 P. (2d) 503, involved in part the allegation of negligence due to the failure of the defendant, who practiced in Ontario, to treat the patient after sbe had moved to San Bernardino. The court in discussing the creation and nature of the physician-patient relationship spoke as follows: "The relation of physician and patient is, in its inception, created by contract either express or implied. The contract may be general or may be limited by special terms. When general, the physician may undertake the treatment of a patient during the course of an illness wherever the patient may be. A physician is under no obligation to enter into such a general contract for such treatment of a patient. He may himit his obligation by undertaking to treat the patient only for a certain ailment or injury at a certain place and at a specified time. When he so limits his employment the physician is not required to treat his patient at another place nor to follow him into another city." Ibid. at 204, 97 P. (2d) at 507. 
the physician and a third party. ${ }^{3}$ The relationship has been described as consensual $;{ }^{4}$ from the relationship contractual duties are usually implied.

A brief consideration of Kramer v. Policy Holders Life Insurance Association, ${ }^{5}$ which interprets section 1881, subdivision 4 of the Code of Civil Procedure, will make plain what is necessary in California to create the physician and patient relationship. Except under certain specified circumstances, section 1881, subdivision 4 requires the consent of the patient when a licensed physician or surgeon discloses information "acquired in attending the patient which was necessary to enable him to prescribe or act for the patient".

In the Kramer case the patient was examined at a free cancer clinic by a Dr. Harris who was paid not by the clinic but by a third party and who had no intention of treating her himself. Dr. Harris' presence at the clinic was for the purpose of advising the donor of the funds by which the clinic was operated concerning the efficacy of a particular cancer treatment. There was no conversation between Dr. Harris and the patient as to the purpose of the physical examination which he made. The appointment for the physical examination was made either through the doctor's stenographer or through a clerk of the clinic, not with the doctor himself. The court found the examination of Dr. Harris "indispensable to the treatnient received and a part thereof"' and held that the relationship of physician and patient was created by the examination made and accepted.

A difference in the wording of two provisions of section 1881, subd. 4 of the Code of Civil Procedure provides a real basis for the contention that the physician-patient relationship may be created when no treatment of the patient by anyone is contemplated. In the provision establishing the physician-patient relationship as privileged

\footnotetext{
3 The request that a physician treat an adult child does not, however, in the absence of an express agreement to pay therefor give rise to an implied promise to pay. And the physician may not be able to collect from the patient, though the relationship of physician and patient has been clearly established! See McClenahan v. Keyes (1924) 65 Cal. App. 467, 224 Pac. 241, related case (1922) 188 Cal. 574, 206 Pac. 454. See Zumwalt v. Schwarz (1931) 112 Cal. App. 734, 297 Pac. 608 (physician who summoned another physician to assist a critically ill patient not liable for the services requested and rendered); Scott v. Monte Cristo Oil and Development Co. (1911) 15 Cal. App. 453, 115 Pac. 64 (moral obligation was sufficient consideration for agreement by corporation's president to pay physician for services to employee).

441 Axr. Jor. 193 (Physicians and Surgeons \$71).

(1935) 5 Cal. App. (2d) 380, 42 P. (2d) 665.

Ibid. at 390,42 P. (2d) at 670.
} 
the words "prescribe or act for the patient" are used. In the provision which excepts the relationship from protection in case of a suit by the patient for damages for personal injuries the words employed are "prescribed or treated". Webb v. Francis J. Ewald Coal Co." holds that "the word 'act' has a broader scope and meaning than the word 'treat'". 8 A physician acting for a patient may not be treating him, but nevertheless the physician-patient relationship under the $W e b b$ case would exist.

Under a liberal construction of the word "act" the rendering of any service in relation to a patient which involves the medical knowledge and skill of a physician, although treatment is not contemplated, ${ }^{9}$ will in California establish the relationship with its consequent liabilities, unless the particular facts of the case bring it under a statutory or a recognized judicial exception. Clearly, however, under the Kramer case the relationship of physician and patient comes into existence when the physician, for whatever motive and at whosoever's direction, makes an examination, oral or physical, of the patient, if the examination is made in contemplation of treatment by someone and is designed to facilitate such treatment.

The relationship of physician and patient, while it may be contractual, often exists in the absence of elements necessary in the typical express contract situation.

b. Duration and termination of the relationship. The duration and termination of the relationship of physician and patient are under the absolute control of the patient. The patient may at any time for any reason or for no reason dismiss the physician. Public policy requires the physician, on the contrary, to continue treatment as long as needed ${ }^{10}$ and to render it as frequently as required by the

\footnotetext{
T (1931) 214 Cal. 182, 4 P. (2d) 532, 77 A. L. R. 675.

8 See also supra note 5, at 389, 42 P. (2d) at 669; McRae v. Erickson (1905) I Cal. App. 326, 82 Pac. 209.

8 It would appear, for instance, that the examination by a physician of a participant in an athletic contest before the contest, where clearly no treatment is contemplated, would establish the physician-patient relationship to the extent that if the advice given the athlete is based on a careless and negligent examination and such advice is relied on to the atblete's harm, an action for damages would lie against the physician, notwithstanding the fact that the physician was not retained by the athlete.

10 Lathrope v. Flood (1901) 6 Cal. Unrep. 637, 63 Pac. 1007, reversed in (1901) $135 \mathrm{Cal} .458,67 \mathrm{Pac} .683$ on other grounds, involved abandonment in a child-birth case when the mother strenuously objected to a forceps delivery. The court found a "wanton disregard ... of professional ethics" (Ibid. at 640,63 Pac. at 1008) and a negligence "amounting well nigh to brutality" (Ibid. at 639, 63 Pac. at 1008). The
} 
standards of care governing such matters. ${ }^{11}$ Subject to a showing of lack of due care, the physician is the judge of the frequency of visits required by the patient's illness. ${ }^{12}$

c. Fiduciary nature of the relationship. The relationship of physician to patient is that of a fiduciary; utmost good faith is required at all times. The learning, skill and authority of the physician on the one hand and the dependence and illness of the patient on the other cause the two to meet as unequals.

The California rule is well stated in Cole $v$. Wolfskill: ${ }^{13}$

"It undoubtedly is the established rule that the relation of physician and patient is confidential; and the law demands the strictest good faith and fair dealing in all transactions arising from that relationship. Once this relation is shown to exist, all dealings between the parties will be closely scrutinized to ascertain if the confidence of the trusting party has been betrayed or his mind unduly influenced to his prejudice."14

The existence of the confidential relationship will not, however, prevent the free and voluntary disposition of property by the patient to the physician. The discretion of the trial court in determining whether the presumption of undue influence has been overcome is controlling..$^{15}$

Lathrope case is cited in Williams v. Tarter (1941) $151 \mathrm{~S}$. W. (2d) 783, $286 \mathrm{Ky} .717$, and the principle of it recognized as controlling in a similar set of facts. See (1942) 142 A. L. R. 111 for annotation on "Duty and liability of physicion or surgeon in pregnancy and childbirth cases." The physician may withdraw from a case after proper notice and when arrangements are completed for a substitute.

11 Hopkins v. Heller (1922) 59 Cal. App. 447, 452, 210 Pac. 975, 97 R. C. L. 389 on scope and extent of duty of physician and surgeon); Taylor v. De Vaughn (1928) 91 Cal. App. 318, 266 Pac. 960 (removal of patient from hospital before fracture had healed did not break relation of physician and patient).

12 See Neudeck v. Vestal (1931) 117 Cal. App. 266, 268, 269, 3 P. (2d) 595, 596. "But where the action is for harmful neglect we find no authority for holding the physician is the sole judge of the frequency and necessity of his visits, the rule being that a physician is not chargeable with neglect in allowing intervals to elapse between his visits where the patient needs no attention during the intervals, but he is neghgent in doing so where attention is needed."

13 (1920) 49 Cal. App. 52, 192 Pac. 549; see Schurman v. Look (1923) 63 Cal. App. 347, 218 Pac. 624.

14 (1920) 49 Cal. App. at 54, 192 Pac. 549.

1520 Cax. Jur. 1072, 1073 (Physicians and Surgeons $\S 20$ ); Macaulay v. Booth (1942) 53 Cal. App. (2d) 757, 763, 128 P. (2d) 386, 388; see Pashley v. Pacific Electric Co. (1944) 25 A. C. 222 , at 231,153 P. (2d) 325 , at 329,330 , (not a malpractice case), where the "duty of refraining from fraudulent concealinent, that is, the duty of disclosure when he (physician) (has) knowledge of the facts" is recognized in the relationship of physician and patient. 
II.

\section{NEGLTGENCE AND THE STANDARD OF CARE}

a. Dentists. The California cases make no differentiation between dentists and physicians as to negligence. ${ }^{10}$ The standard of care required of each is the same, though the dentist is not expected to possess the same kind of skill or knowledge as a physician.

b. Accepted formulation of standard of care. Although the cases are not umiform, ${ }^{17}$ the most recent decisions accept the statement of the required standard of care made in Trindle $v$. Wheeler: ${ }^{18}$

"The law requires that the physician shall have the degree of learning and skill ordinarily possessed by physicians of good standing practicing in the same locality and that he shall use ordinary care and diligence in applying that learning and skill to the treatment of his patient." 19

An analysis of this criterion shows that the highest standard of knowledge or care is not required. ${ }^{20}$ It is demanded only:

1) that the physician possess ordinary learning and skill, according to what may be reasonably expected in the light of practices existing in the same locality;

2) that the physician use ordinary diligence and care in applying his learning and skill.

The statement of the standard to be applied sometimes is phrased with the explicit qualification of "having regard to the state of scientific learning at the time". ${ }^{21}$ If not expressed, this qualification is implicit in the usual statement of the standard.

c. Standard of care required of a specialist. The standard of care required of a physician who holds himself out as a specialist is that he possess the degree of learning and skill ordinarily possessed

16 "There is no legal distinction between an action against a dentist for malpractice and a similar one against a physician." Roberts v. Parker (1932) 121 Cal. App. 264, 267, 8 P. (2d) 908, 909; see also Walter v. England (1933) 133 Cal. App. 676, 679, 24 P. (2d) $930,931$.

17 See Restatearent of Torts (California Annotations 1940) $\$ 299$, p. 126, for a list of California cases which do not include the "locality" qualification in the standard of care imposed.

18 (Dec. 18, 1943) 23 Cal. (2d) 330, 143 P. (2d) 932.

19 Ibid. at 333,143 P. (2d) at 933.

20 "Proper treatment" is not required. Such a standard implies that an approximately perfect result will be achieved. Rasmussen v. Shickle (1935) 4 Cal. App. (2d) 426, 429, 41 P. (2d) 184, 185.

21 See McBride v. Saylin (1936) 6 Cal. (2d) 134, 138, 56 P. (2d) $941,943$. 
by a specialist practicing in the locality and that he employ this learning and skill with the care and diligence such a typical specihist uses. ${ }^{22}$ In short, the same degree of care is required of a specialist as is deinanded of a general practitioner, but the amount of skill is much greater. It may be expected that the average specialist possesses greater skill and learning in his particular field than one who does not hold himself out as such.

d. Errors of judgment. The holding out of oneself as a physician or surgeon constitutes a representation that one possesses a reasonable degree of learning and skill. ${ }^{23}$ Lack of such skill or failure to einploy reasonable diligence in the use of it will ordinarily be actionable negligence. But errors in judgment are not ground for liability unless the skill and judgment actually employed fall below standard. ${ }^{24}$ Likewise it is no defense that one used his best judgment if such best judgment falls below the standard set by the typical practitioner in that or a similar community or locality. ${ }^{25}$

e. Tort nature of malpractice action. Actions for malpractice are regarded as actions not on contract but in tort. ${ }^{26}$ Negligence must be proved and causal connection between the defendant's conduct and the injury shown. Negligence consists in doing something that the physician should not have done or in omitting to do something which

22 Sansom v. Ross-Loos Medical Group (1943) 57 Cal. App. (2d) 549, 555, 556, 134 P. (2d) 927, 931; see also Hopkins v. Heller (1922) 59 Cal. App. 447, 452, 210 Pac. 975, 976, 977; Pearson v. Crabtree 1924, 70 Cal. App. 52, 232 Pac. 715 (X-ray specialist is held only to reasonable skill and care usually exercised by others in his field in the commumity).

23 Kershaw v. Tilbury (1932) 214 Cal. 679, 8 P. (2d) 109; Hesler v. California Hospital Co. (1918) 178 Cal. 764, 174 Pac. 654; Sim v. Weeks (1935) 7 Cal. App. (2d) 28, 33, 45 P. (2d) 350, 352 ; Sansom v. Ross-Loos Medical Group (1943) 57 Cal. App. (2d) $549,552,553,134$ P. (2d) $927,929$.

24 Scott v. McPheeters (1939) 33 Cal. App. (2d) 629, 637, 92 P. (2d) 678, 683, 93 P. (2d) 562 .

25 "That a practicing physician may bave done his best is no answer to an action of this sort." Reynolds v. Struble (1933) 128 Cal. App. 716, 725, 18 P. (2d) 690; Callahan v. Hahnemann Hospital (1934) 1 Cal. (2d) 447, 35 P. (2d) 536; Donahoo v. Lovas (1930) 105 Cal. App. 705, 288 Pac. 698; Sim v. Weeks, supro note 23, at 36, 37, 45 P. (2d) 350 at 354.

26 "It is the settled law in this state that an action by a patient against a physician and surgeon for injuries sustained by the former, by reason of the negligent or unskilled treatment of the latter, is an action sounding in tort and not upon contract." Huysman v. Kirsch (1936) 6 Cal. (2d) 302, 306, 57 P. (2d) 908, 910. See also Pillsbury v. Title Insurance and Trust Co. (1917) $175 \mathrm{Cal} .454$, $166 \mathrm{Pac}$. 11, 3 A. L. R. 1396: "An action for malpractice may have its basis either in a wilful injury, an injury occasioned by negligence, or, finally, in the doing of that which is forbidden by positive law. But in every instance the action sounds in tort." Ibid. at 460, 166 Pac. at 14. 
he should have done. ${ }^{27}$ Liability is imposed in the absence of negligence in certain cases of excess of authority when the physician or surgeon is technically guilty of an assault, or when responsibility for the negligence of a third party is placed upon the physician. It is axiomatic that consent for an operation must be secured.

f. Classification of malpractice cases. The decision in Callahan v. Hahnemann Hospital" recognizes "three main classes of cases in which malpractice has been charged": ${ }^{29}$

1) those charging unskilfulness in diaguosis;

2) those charging unskilfulness in the selection of a method of treatment;

3) those charging unskilfulness in some act or omission on the part of the physician in administering the treatment.

g. Diagnosis. Failure to make a correct diagnosis of the patient's malady is not actionable in the absence of a showing of lack of ordinary care, diligence, and skill..$^{30}$ The absence of expert testimony showing that the diaguosis violated the standard of care required will prevent recovery.1 "Diagnosis terminates only when the physician learns at least to his own satisfaction the nature of the ailment." ${ }^{132}$ Failure of the patient to recover creates no inference of incorrect diagnosis or improper treatment, for a cure is not gnaranteed in the

27 Peppercorn v. Stewart (1931) 114 Cal. App. 101, 104, 299 Pac. 762, 763. See also Sim v. Weeks, supra note 23 , at 33,45 P. (2d) at 353 .

28 (1934) I Cal. (2d) 447, 457, 35 P. (2d) 536, 541.

29 An adjudication in a physician's suit to recover for services rendered, even in a default case, is also an adjudication of any possihle malpractice action which patientdefendant could have raised. The patient must take care not to lose his rights by neglecting to assert them in such a suit. See Olney v. Cavell (1934) 138 Cal. App. 233, 32 P. (2d) 181.

The statute of limitations for the debt incurred for the physician's services is four years (CAL. Codz Crv. Proc. § 337) and for a malpractice action one year (Ibid. § 340). By refraining from suit for payment of his services longer than one year after the termination of such services, the physician will escape a counter-claim for malpractice.

30 "The same degree of responsibility is imposed in the making of a diagnosis as in the prescribing and administering of treatment." Lawless v. Calaway (1944) 24 Cal. (2d) 81, 86, 147 P. (2d) 604, 606. See also Ries v. Reinard (1941) 47 Cal. App. (2d) $116,119,117$ P. (2d) 386, 388, hearing den.

In an action for damages for malpractice, "mere proof that a diagnosis was wrong or that a treatment was unsuccessful will not support a verdict." Nicholas v. Jacobson (1931) 113 Cal. App. 382, 386, 298 Pac. 505, 507.

31 Rising v. Veatch (1931) 117 Cal. App. 404, 409, 3 P. (2d) 1023, 1024.

32 Reynolds v. Struble, supra note 25, at 724, 13 P. )2d) at 694 . 
absence of an express contract..$^{33}$ In the absence of evidence to the contrary there is a presumption of reasonable skill and care, which is not negatived by showing merely a failure of the treatment to achieve healing. ${ }^{34}$

Advice against the extraction of an ulcerated wisdom tooth in the mistaken belief, after examination, that the woman was pregnant gave no ground for recovery against the physician consulted..$^{35}$ Diagnosis and treatment of appendicitis as ptomaine poisoning, though the possibility of appendicitis was recognized from the beginning, has been held not actionable negligence. ${ }^{36}$ Failure to read correctly a clear X-ray picture so as to note a fracture of the neck of the scapula, even though the $\mathrm{X}$-ray was taken with a view primarily to determining a possible chest condition, is conduct indicating unskilful diagnosis. ${ }^{37}$ When, however, the patient refuses to go to a hospital where $\mathrm{X}$-ray equipment is available, the failure to use an $\mathrm{X}$-ray machine in diagnosing and reducing a fractured $\operatorname{limb}$ is not necessarily negligence. ${ }^{38}$

h. School of medicine to which defendant belongs. With regard to the skill and care required in diagnosis and treatment the rule is that the physician is to be judged by the peculiar standards and principles of the school of medicine to which he belongs. If the diagnostic method or type of treatment is not peculiar to a school, then practitioners familiar with such diagnostic inethod or such type of treatment may testify, although they are not members of the defendant's school. In Hutter v. Hommel, ${ }^{39}$ a homeopathic physician and surgeon testified against an allopath on matters having to do with sterilization of instruments and the prevention of infection. In Dalton $v$.

33 Hall v. Steele (1924) 193 Cal. 602, 226 Pac. 854; Say v. Barber (1927) 202 Cal. 679, 262 Pac. 312; Nelson v. Painless Parker (1930) 104 Cal. App. 770, 286 Pac. 1078; Abos v. Martyn (1939) 31 Cal. App (2d) 705, 88 P. (2d) 797.

84 Rasmussen v. Shickle (1935) 4 Cal. App. (2d) 426, 429, 430, 41 P. (2d) 184, 185.

35 "There was in the present case no expert evidence as to what method or means, in the exercise of ordinary care and skill, should have been employed to determine the presence or absence of pregnancy. On the record presented it is reasonable to conclude, in harmony with the holding of the trial court, that there was no showing of negligence on the part of the defendant in making the mistaken diagnosis, having in mind the standards of proof required." Patterson v. Marcus (1928) 203 Cal. 550, 553; 265 Pac. $222,223$.

36 Lawless v. Calaway, supra note 30.

37 Reynolds v. Struble, supra note 25, at 723, 18 P. (2d) at 693.

38 Bickford v. Lawson (1938) 27 Cal. App. (2) 416, 420, 421 ; 81 P. (2d) 216, 219.

39 (1931) 213 Cal. 677, 681, 3 P. (2d) 554, 556. 
Los Angeles College of Chiropractic ${ }^{40}$ testimony on diathermy by a non-chiropractic doctor was permitted against a chiropractor. In Ellinzwood v. McCoy, ${ }^{41}$ relying on Hutter v. Hommel, it was held that physicians other than drugless practitioners or chiropractors could testify concerning the treatment given by the defendant, a drugless practitioner, "where the alleged malpractice is based upon general charges of negligence relating largely to matters of almost common observation within the experience of every physician and surgeon". In $A b o s$ v. Martyn $n^{29}$ the testimony of physicians was allowed against a chiropractor where the treatment was for paralysis diagnosed as caused by a spinal maladjustment, when an autopsy showed no abnormal spine condition but a tuberculous condition not revealed by X-rays taken by the defendant. ${ }^{43}$ In Mirich v. Balsinger ${ }^{44}$ testimony was permitted against a plastic surgeon by a physician who was not a plastic surgeon but who was familiar with the work of eminent plastic surgeons. ${ }^{45}$

i. Selection of method of treatment. In the selection of a method of treatment the law recognizes that the most skilful members of the medical profession will often honestly and reasonably differ. It is usually required that the physician keep within "recognized and approved methods". ${ }^{46}$ In Kershaw $v$. Tilbury the treatment given consisted of "radio methods". Dr. Tilbury, an osteopathic physician, claimed to have invented a new kind of treatment, concerning which he alone was qualified to speak. The court held that it passed no opinion on the method but considered results. "One who holds himself out as a medical expert and accepts employnent as a healer of diseases, but who relies for diagnosis and remedies on some mechanical invention of his own, which invention is unknown to all schools

10 (1932) 125 Cal. App. 196, 200, 201; 13 P. (2d) 546.

41 (1935) 8 Cal. App. (2d) 590, 594; 47 P. (2d) 796, 797.

42 (1939) 31 Cal. App. (2d) 705, 713, 714; 88 P. (2d) 797, 801.

43 The Abos case appears to go rather far in permitting expert testimony by members of another school. See Howe v. McCoy (1931) 113 Cal. App. 468, 298 Pac. 530 (where chiropractors testified as to standard of care required of a chiropractor).

414 (1942) 53 Cal. App. (2d) 103, 118; 127 P. (2d) 639, 646.

45 An expert witness is not disqualified merely because he is unfamiliar with the particular method of treatment employed by defendant, e. g. the so-called "Percy cautery" method in cancer operations. Valdez v. Percy (1939) 35 Cal. App. (2d) 485, 493; 96 P. (2d) $142,146$.

48 Callahan v. Hahnemann Hospital, supra note 25 , at 458,35 P. (2d) at 541 . This rule penalizes the brilliant innovator and pioneer in medical science.

4 (1932) 214 Cal. 679; 8 P. (2d) 109, reh'g den. 
of medical science, in like manner takes the risk of the quality and accuracy of such mechanical invention."

Negligence is not shown by proving that other medicines or other types of treatment might have been employed." "A charge of negligence in a choice of treatment is refuted as a matter of law by showing that a respectable minority of expert physicians approved the method selected." Evo Evidence of lack of ordinary care, however, in the selection of a method of treatment, notwithstanding the fact that the physician used his best judgment, presents a jury question. ${ }^{\mathbf{5 1}}$

The secondary importance in the determination of negligence of the particular mode of treatment employed is clearly indicated in Thomason v. Hethcock: ${ }^{52}$

"The question which the jury must ultimately decide is not whether the treatment administered is such as would be commonly adopted and administered by doctors of ordinary skill in the use of ordinary care, but ... whether the treatment administered or the method used, whether a common method of treatment or not, was such, or was given in such a manner as indicated, suggested, or demonstrated a lack of that care, training, and skill which is ordinarily possessed by physicians and surgeons practicing in the same or similar communities."

j. Duty of referral. A physician is under a duty to recommend or advise treatment by some one more qualified to give treatment if the patient's condition requires it. An instruction that advice not to consult a physician or surgeon for treatment after the patient's condition grew worse under her dentist's care was to be considered in fixing the damages sustained was upheld in Mernin v. Cory. ${ }^{54}$

k. Examples of negligent acts in treatment. In California the following acts or situations are among those which have been found to indicate a failure to achieve the standard of care which the physician or dentist must observe in his treatment of the patient: improper preparation of mixture used in making impressions by dental sur-

$18 \mathrm{Ibid}$. at $693,8 \mathrm{P}$. (2d) at 115.

49 Jensen v. Findley (1936) $17 \mathrm{Cal}$. App. (2d) 536, 543; 62 P. (2d) 430, 434.

50 Sim v. Weeks, supra note 23 , at 37,45 P. (2d) at $354,355$.

51 See Langford v. Kosterlitz (1930) 107 Cal. App. 175, 189; 290 Pac. 80, 85, 86. (where instruction on experimenting in a delicate operation was upheld, the allegation of neghigence "being broad enough to include experimenting".)

52 (1935) 7 Cal. App. (2d) 634; 46 P. (2d) 832.

53 Ibid. at $636 ; 46$ P. (2d) at 833 .

64 (1904) 145 Cal. 573, 575, 576; 79 P. 174, 175. See (1941) 132 A. L. R. 392. 
geon's temporary assistant with resultant burns to patient's mouth; acute flexion of elbow joint.and tight bandaging of left arm in treatment of fracture of humerus, ischemic paralysis resulting; ${ }^{56}$ failure to extract tooth fragment and improper fitting denture; ${ }^{50}$ excessive heat application from infra-red incandescent lamp by physician's nurse while patient was under opiates; ${ }^{5 \varepsilon}$ application of cast to wrist so tightly as to impede circulation and retention of cast over a long period of time during which excessive diathermy was used; ${ }^{\text {to }}$ leaving a sponge fourteen inches square in an abdominal cavity upon the completion of an operation and permitting same to remain undiscovered for five weeks $;{ }^{60}$ failure to detect abscess in foot and to open and drain the point of infection; ${ }^{\mathrm{C1}}$ diagnosis and treatment of bone infection by a "radio method" device invented by individual holding self out as a healer of diseases; ${ }^{\text {B2 }}$ failure to take X-rays of broken arm frequently enough to keep informed of progress of healing and failure to maintain traction and cast on arm for a sufficient length of time with resultant absence of correction of angnlation of union; ${ }^{03}$ presence of needle $2 \frac{1}{2}$ to 3 inches long in psoas muscle discovered several months after an operation for a ruptured appendix $;^{04}$ failure to take X-ray to discover cause of inflamed and swollen condition of gums or to reduce infection before injecting anaesthetic into gum and extracting tooth ${ }^{65}$ breaking of anaesthetic needle inserted in cartilage of jaw $;^{B 8}$ failure to observe sterilization precautions in removal of a cyst; ${ }^{\mathrm{B7}}$ insertion of cold quartz rod (ultra violet ray orifical

\footnotetext{
55 Ley v. Bishopp (1928) 88 Cal. App. 313, 263 Pac. 369, hearing den. (Motion for non-suit held properly denied-it should be borne in mind that in this and the cases which follow if the verdict finds reasonable support in the evidence, it will be upheld).

${ }^{56}$ Sim v. Weeks (1935) 7 Cal. App. (2d) 28; 45 P. (2d) 350 . See also Priestly v. Stafford (1916) 30 Cal. App. 523, 158 Pac. 776.

57 Blakeslee v. Tannlund (1938) 25 Cal. App. (2d) 32, 76 P. (2d) 216.

58 McCullough v. Langer (1937) 23 Cal. App. (2d) 510, 73 P. (2d.) 649.

59 Wallace v. La Vine (1940) 36 Cal. App. (2d) 450, 97 P. (2d) 879.

60 Armstrong v. Wallace (1935) 8 Cal. App. (2d) 429, 47 P. (2d) 740.

61 Sales v. Bacigalupi (1941) 47 Cal. App. (2d) 82,117 P. (2d) 399.

62 Kershaw v. Tilbury (1932) 214 Cal. 679, 8 P. (2d) 109. 927.

63 Sansonu v. Ross-Loos Medical Group (1943) 57 Cal. App. (2d) 549, 134 P. (2d)

64 Sugaya v. Morton (1935) 4 Cal. App. (2d) 61, 40 P. (2d) 581.

65 Roberts v. Parker (1932) 121 Cal. App. 264, 8 P. (2d) 908.

00 Walter v. England (1933) 133 Cal. App. 676, 24 P. (2d) 930.

${ }^{67}$ Hutter v. Hoinmel (1931) 213 Cal. 677, 3 P. (2d) 554. See also Dimock v. Miller (1927) $202 \mathrm{Cal} .668,262 \mathrm{Pac}$. 311 (where dentist failed to enploy sterilization in use of hypodermic needle), also Barham v. Widing (1930) 210 Cal. 205, 291 Pac. 173; Soest v. Balsinger (1943) 60 Cal. App. (2d) 441, 141 P. (2d) 13.
} 
applicator) in patient's urethra and excessive heating with resultant third degree burns ("case which had been traumatized through brutal instrumentation"); ${ }^{68}$ failure to take X-ray of finger and to employ extension by use of splints to reduce fracture; ${ }^{68}$ failure to consult with previous physician as to condition of patient's nose before performing an operation for asthma, operation being marked by "experimenting" and followed by loss of sight in right eye; ${ }^{70}$ failure to have X-rays taken and treatment of fractured hip bone as a dislocated hip; "kn "knocking out of tooth" of patient under anesthetic preparatory to operation for removal of tonsils, no testimony appearing as to how tooth was loosened and removed; ${ }^{i 2}$ application of pressure in a chiropractic adjustment for sciatica, resulting in tearing and breaking of cartilage of one of lower ribs ${ }^{73}$ placing of unidentified substance in eye after operation for cataract, with resultant loss of sight; ;4 plastic surgery operation on nose, which was followed by excessive growth of scar tissue and shrinkage of nasal passages; ${ }^{75}$ injection of formalin inadvertently supplied by hospital nurse in lieu of novocain in operation for removal of cyst on groin; ${ }^{\text {To }}$ removal by plastic surgery of skin from lower lip in such a way as to cause it to droop on each side; ${ }^{77}$ dropping tooth down boy's throat after extraction, patient suffering several attacks of pneumonia in six years before tooth was coughed up; ${ }^{78}$ unskilful operation by dental nurse of $\mathrm{X}$-ray machine, resulting in first and second degree burns. ${ }^{78}$

1. Examples of acts found not negligent. The following acts, types of conduct, or situations are among those which have been held not to indicate a violation of the standard of care which the physician or surgeon must observe in his diagnosis or treatment of the patient: use of silk sutures in second operation when after first operation

\footnotetext{
68 Ellinwood v. McCoy (1935) 8 Cal. App. (2d) 590, 47 P. (2d) 796.

60 Smith v. Coleman (1941) 46 Cal. App. (2d) 507, 116 P. (2d) 133.

70 Langford v. Kosterlitz (1930) 107 Cal. App. 175, 290 Pac. 80.

11 Rankin v. Mills (1929) 207 Cal. 438, 278 Pac. 1044.

72 Brown v. Shorthige (1929) 98 Cal. App. 352, 277 Pac. 134:

73 Howe v. McCoy (1931) 113 Cal. App. 468, 298 Pac. 530.

74 Dean v. Dyer (1944) $64 \mathrm{Cal}$. App. (2d) 646, 149 P. (2d) 288, hearing den.

75 Mirich v. Balsinger (1943) 53 Cal. App. (2d) 103, 127 P. (2d) 639.

76 Hallinan v. Prindle (1936) 17 Cal. App. (2d) 656, 62 P. (2d) 1075. See also: Halliman v. Prindle (1934) 220 Cal. 46, 29 P. (2d) 202.

7 Hall v. Steele (1924) 193 Cal. 602, 226 Pac. 854.

78 Nelson v. Painless Parker (1930) 104 Cal. App. 770, 286 Pac. 1078.

79 Ragin v. Zimmerman (1929) 206 Cal. 723, 276 Pac. 107.
} 
hemorrhage occurred because of use of catgut; ${ }^{80}$ mjection of glucose solution subcutaneously to a "dying patient" after an operation for a ruptured appendix, recovery being accompanied by a sloughing of tissue at point of injection; ${ }^{81}$ existence at end of two months' treatment of mjured arm of following condition: 1) dislocation of radius at elbow, 2) no union of ends of fractured bones, 3) wire broken which was used in securing fractured bones, 4) pus in wound; ${ }^{82}$ removal of adenoids after hospital anaesthetist not under physician's direction had admimistered an excessive amount of ether; ${ }^{83}$ injection of alcohol into sciatic nerve in order to relieve pain in hip and foot; ${ }^{84}$ allowing a portion of kidney and ureter to remain in an operation to relieve condition caused by functionless kidney; ${ }^{35}$ diagnosis of gonorrhea on basis of methylene blue test when practice of physicians in community was to use either methylene blue or gram negative stain tests; ${ }^{80}$ failure to hospitalize patient suffering from gonorrheal ophthalmia or to take a smear from eye ${ }^{87}$ difficult tooth extraction, followed by extended painful condition of jaw, which condition was partly relieved by an operation by another dentist ten months later; ${ }^{88}$ failure to take second $\mathrm{X}$-ray of elbow wounded by gunshot until over three months after operation and referral of case at that time to more experienced surgeon. ${ }^{89}$

80 Linn v. Peirsol (1918) 37 Cal. App. 171, 173 Pac. 763 (trial court's denial of motions for non-suit and directed verdict beld erroneous).

81 Callahan v. Hehnemann Hospital (1934) I Cal. (2d) 447, 35 P. (2d) 536 (judgment for plaintiff reversed with directions to enter judgment for defendant).

82 Houghton v. Dickson (1916) 29 Cal. App. 321, 155 Pac. 128 (judgment for plaintiff and denial of motion for new trial reversed); Peppercorn v. Stewart (1931) 114 Cal. App. 101, 299 Pac. 762 (judgment of non-suit affirmed).

83 Stonaker v. Big Sisters Hospital (1931) 116 Cal. App. 375, 2 P. (2d) 520 (directed verdict for defendants affirmed).

84 Donahoo v. Lovas (1930) $105 \mathrm{Cal}$. App. 705, $288 \mathrm{Pac} .698$ (order and judgment for non-suit at close of plaintiff's evidence affirmed).

85 Johnson v. Clarke (1929) 98 Cal. App. 358, 276 Pac. 1052 (expert testimony held conclusive on appeal; judgment for plaintiff reversed; defendant's motion for a new trial granted).

86 Ries v. Reinard (1941) 47 Cal. App. (2d) 116, 117 P. (2d) 386 (judgment of trial court without jury for defendant sustained).

87 Jensen v. Findley (1936) 17 Cal. App. (2d) 536, 62 P. (2d) 430 (instructed verdict at close of plaintiff's evidence affirmed).

88 Hopkins v. Heller (1922) 59 Cal. App. 447, 210 Pac. 975, hearing den. (judgment for plaintiff reversed).

89 Scherer v. Eidenmuller (1919) 45 Cal. App. 372, 187 Pac. 445 (judgment for plaintiff reversed). 
m. Comprehensiveness of term "locality" in standard of care. In California the most recent cases state the applicable standard of care in terms of the practices of the defendant's locality. ${ }^{80}$ The question of what a locality is arises in the qualifying of expert witnesses, for obviously an expert witness must be familiar with the practices in the defendant's community or locality in order to testify concerming the standards prevailing there. ${ }^{91}$

The leading cases on the nature and extent of a locality have involved the metropolitan areas of Los Angeles and San Francisco. In Lewis v. Johnson ${ }^{92}$ the court held it error to exclude the testimony of doctors practicing in Los Angeles as to the standards of care prevailing in Long Beach. ${ }^{93}$ In Sales v. Bacigalup $i^{94}$ an Oakland plyysician was held qualified to testify to the method customarily used in San Francisco to treat an infection. ${ }^{95}$ In Warnock $v$. Kraft ${ }^{96}$ the first case to consider at length the significance of the term "locality" in connection with the standard of care imposed in malpractice cases, a Los Angeles plyysician was held competent to testify concerming a practitioner in Pasadena. ${ }^{\text {gr }}$

00 Some cases use the expression "vicinity" instead of "locality", Howe v. McCoy, supra note 73; Langford v. Kosterlitz, supra note 51 . Steiner v. Goodyear Tire \& Rubber Co. (1931) 115 Cal. App. 162, 300 Pac. 980 uses the expression "in the same or a similar locality", ibid. at 163, 300 Pac. at 981; also McNamara v. Emmons, supra note 2, but the McNamara case relies on Patterson v. Marcus (1928) 203 Cal. 550, 265 Pac. 222, that does not include in the statement of the standard any "locality" qualification at all. Hesler v. Calif. Hospital (1918) 178 Cal. 764, 174 Pac. 654, also cited by McNamara v. Emmons, does not lay down the standard of a "similar locality" but rather that of the locality where the physician practices, ibid. at 767, 174 Pac. at 655. The "similar locahity" aspect of the standard is not countenanced by recent cases: see Lawless v. Calaway (April 6, 1944) 24 Cal. (2d) 81, 86, 147 P. (2d) 604, 606. Obviously if the standard to be applied may be that of practices in a "similar locality", any "similar locality" may be chosen which best supports the plaintiff's or defendant's contentions. Localities similar in population and economic wealth and in other significant ways may still conceivably vary greatly in standards of medical practice. A similar problem arises in the determination of proper fees for the services rendered by the physician. See Citron v. Fields (1938) 30 Cal. App. (2d) 51, 85 P. (2d) 534.

01 Pierce v. Paterson (1942) 50 Cal. App. (2d) 486, 491, $123 \mathrm{P}$ (2d) 544, 547.

92 (1939) $12 \mathrm{Cal}$. (2d) 558, 86 P. (2d) 99.

83 "The cities of Long Beach and Los Angeles are both in the same county; they are contiguous communities, both metropolitan in character, and their business centers are only about 25 miles apart." Ibid. at 561, $86 \mathrm{P}$. (2d) at 101.

of (1941) 47 Cal. App. (2d) 82, 117 P. (2d) 399.

95 "In view of the close proximity of the two cities and the metropolitan character of the entire area this sufficiently qualifies him." Ibid. at 86, 117 P. (2d) at 401, 402.

98 (1938) 30 Cal. App. (2d) 1, 85 P. (2d) 505.

87 "The theory supporting the rule of law above stated is that a doctor in a small commumity or village, rot having the same opportunity and resources for keeping abreast 
The primary factors which determine the comprehensiveness of the term "locality" (by "comprehensiveness" is meant whether two specific places or two specific cities or towns are included in the locality) in a particular case would appear to be the following:

1) contiguity or close proximity of the districts claimed to be embraced in the locality, ${ }^{\text {, }}$

2) equality of opportunity for professional improvement in districts,

3) accessibility to the same kind of medical facilities throughout the districts embraced in the locality,

4) same predominant economic development (i. e. rural or metropolitan) in districts embraced within the locality.

It is, of course, conceivable that in the future physicians practicing in Los Angeles will be permitted to testify as to the standards of medical care prevailing in San Francisco, for both are large metropolitan centers, but at the present time the rule of contiguity or close proximity of the districts which are to be regarded as included in the "same locality" is strictly observed. If the case is one which depends upon expert testimony, and the witness for the plaintiff can not be qualified because of his lack of knowledge of practices in the locality,

of the advances in his profession, should not be held to the same standard of care and skill as that employed by physicians and surgeons in large cities. . . . It is a matter of common knowledge that the city of Pasadena and the city of Los Angeles are contiguous, are located in the same county, and have the same general hospital; that it is less than twenty miles from the business center of one of such cities to that of the other; and that in the absence of signs marking the city himits of the respective cities one would be unable to determine the boundary line between them. It is a matter of common knowledge also that physicians and surgeons in both cities belong to the same medical society, attend the same lectures, and have available the same facilities for the treatment of patients and for keeping abreast of the advances in their profession." Supre note 96, at $3,4,85$ P. (2d) at 506 .

98 It is essential that the witness to be qualified know the customary practices of physicians practicing in the locality. The witness cannot testify on the basis of his judgment as to the method of treatment which should be employed. Thus in Bickford v. Lawson (1938) 27 Cal. App. (2d) 416, 81 P. (2d) 216, the testimony of a physician practicing for twenty years at Arbuckle concerning the metbod of treatment employed by the defendant physician, practicing for twenty-six years at Willows, 35 miles north of Arbuckle-both Arbuckle and Willows are small rural towns in the Sacramento valley -was excluded as incompetent, "since he did not know what the practice of other physicians in that locahty (Willows)" was. Obviously he knew what the practice was in Arbuckle, 35 miles away, but the "locality", according to the court ruling, was not extensive enough to embrace both Arbuckle and Willows! The Arbuckle pbysician was asked wbetber he knew anything concerning the practices of two Orland physicians. Orland is 16 miles north of Willows. Presumably, therefore, rural towns 16 miles apart are in the same locality. 
a non-suit will be granted.99 The court will "not take judicial notice of the relative heights which the medical profession has attained in various parts of the world."1100

n. When physician's conduct constitutes technical assault and battery. Although the California cases on the subject are $f e w,{ }^{101}$ the law is settled that an operation upon a patient who has not given his consent thereto is technical assault and battery. As such the offense is actionable even in the absence of negligence. The latest California case on this general subject, Valdez v. Percy, ${ }^{10 z}$ involved an operation for the removal of an axillary gland, after which the right breast was removed, presumably on the theory that carcinoma existed, although successive conflicting pathological diagnoses were received by the surgeons during the operation from the laboratory examining the tissue sent to them to report on. A post-operative diagnosis did not indicate breast cancer.

The plaintiff charged that no authority had been given for the removal of her breast. The appellate court reversed the lower court's non-suit on two counts and directed verdict on one count as to the two defendants who actually performed the operation. The Valdez case is authority in California for the following propositions:

1) An operation performed without consent is technical assault and battery; ${ }^{103}$

2) Whether an emergency exists requiring an enlargement or extension of the projected operation previously consented to

99 But if the defendant stipulates to the qualifications of the expert witness and if after such expert witness has made statements showing a lack of knowledge of practices in the locality in question, the defendant presents no request to be relieved of the stipulation or moves to strike the testimony, the defendant can not later object to the qualification of the witness. McGuire v. Baird (1937) 9 Cal. (2d) $353,357,70$ P. (2d) $915,917$.

100 Soady v. Washburn (1931) 114 Cal. App. 82, 84, 299 Pac. 560, 561.

101 Markart v. Zeimer (1924) 67 Cal. App. 363, 367, 227 Pac. 683 (complaint in second count alleged removal of testicle without consent); Adams v. Boyce (1940) $37 \mathrm{Cal}$. App. (2d) 541, 550, 99 P. (2d) 1044 (submission to professional care of physician for removal of forcign body from the eye is such consent as to refute claim of assault and battery) ; Ehlen v. Burrows (1942) 51 Cal. App. (2d) 141, 145, 124 P. (2d) 82, 84 (removal of three sound teeth without consent recognized as an assault). See also Inderbitzen v. Lane Hospital (1932) 124 Cal. App. 462, 468, 12 P. (2d) 744, 747 (physical examinations by ten or twelve different medical students of patient during confinement after she protested held an actionable assault and battery.

102 (1939) 35 Cal. App. (2d) 485, 96 P. (2d) 142.

103 Ibid. at 491,96 P. (2d) at 145. 
by the plaintiff is a question of fact to be submitted to the triers of fact; ${ }^{104}$

3) A pre-operation agreement signed by the plaintiff (and her husband) authorizing in general terms "any and all of the medical and surgical treatments, mcluding operations ... which may be deemed advisable by any of the physicians and surgeons" does not in the absence of proper proof of emergency or necessity arising during the projected operation allow other or different operations; ${ }^{10 \%}$

4) The execution of a pre-operation agreement purportedly authorizing "any and all ... operations" does not absolve the operating physicians from liability for negligence in the performance of any operation which it is contended such authorization covers. ${ }^{106}$

The complaint in the Valdez case contained two "inconsistent" causes of action: an allegation of negligence in treatment, an allegation of an operation without consent (technical assault and battery). The Valdez case is authority for the position that if there is a conflict in the evidence on either theory of the plaintiff's causes of action the granting of a non-suit or a directed verdict is improper.

In Figlietti v. Frick ${ }^{10 \tau}$ the plaintiff joined two counts, one for negligence and the other for operating without consent, in an action for injuries to a minor child who succumbed after an operation. The supreme court held it reversible error to force an election at the trial by the plaintiff between the inconsistent counts.

\section{III.}

PRESENTATION AND PROOF OF THE PLAINTIFF'S CASE

a. Pleading of negligence. It is necessary for the complaint in a malpractice case to allege:

1) facts showing the establishment of the relationship of physician and patient and an undertaking on the part of the physician to render services to the plaintiff; ${ }^{108}$

\section{Ibid.}

$105 \mathrm{Jbid}$.

106 Ibid. at 491, 492, 96 P. (2d) at 145.

107 (1928) 203 Cal. 246, 263 Pac. 534.

108 Guilliams v. Hollywood Hospital (1941) 18 Cal. (2d) 97, 99, 114 P. (2d) 1, 3. 
2) the commission of an act which should not have been done or the omission of an act which should have been done, ${ }^{109}$ judged by recognized practices of the locality where the injury occurred; 110

3) the nature of the injuries suffered by the plaintiff as a proximate result of the neghigent act or omission of the defendant (proximate cause)..$^{111}$

In Califorma, as in most jurisdictions, negligence may be pleaded in general terms. The problem of just how general the allegations in a malpractice case may be in order to avoid a general or special demurrer ${ }^{112}$ has been answered by the leading case of Dunn v. Dufficy $y^{113}$ and clarified by the recent case of Guilliams v. Hollywood Hospital. ${ }^{114}$

In Dunn v. Dufficy the supreme court reversed the lower court's action in sustaining a demurrer for uncertainty against the complaint. ${ }^{115}$ Portions of the complaint are given at length in the supreme court opinion and contain an allegation that the defendant physician failed and neglected to discover a cut tendon in the plaintiff's finger and failed and neglected to sew up the severed tendon. The plaintiff was discharged by the physician as cured with a bent fimger.

109 Foreman v. Hunter Lumber Co. (1918) 36 Cal. App. 763, 765, 173 Pac. 408. It is proper in a complaint for malpractice to allege certain acts of negligence upon information and belief when the causes for the plaintifi's condition are known only to him as a consequence of medical advice. Hearsay evidence is expressly authorized. Mirich v. Balsinger (1942) 53 Cal. App. (2d) 103, 113, 127 P. (2d) 639, 644.

110 Cf. Blakeslee v. Tannlund (1938) 25 Cal. App. (2d) 32, 34, 76 P. (2d) 216, 217. A general demurrer was overruled, although "the complaint did not allege that the appellant had failed to exercise that degree of care and skill ordinarily exercised by persons engaged in the practice of dentistry in the city of Porterville". (Plaintiff was not absolved, however, from establishing such a fact in the proof of his case, ibid. at 35, $76 \mathrm{P}$. (2d) at 217.

111 Reynolds v. Struble (1933) 128 Cal. App. 716, 725, 18 P. (2d) 690, 694.

112 Billesbach v. Larkey (1911) 161 Cal. 649, 120 Pac. 31 (special demurrer for uncertainty upheld). Failure to use word "negligent" in allegation is immaterial if facts constituting negligence are stated-Rankin v. Mills (1929) $207 \mathrm{Cal}$. 438, $278 \mathrm{Pac} .1044$; McGehee v. Shiffmann (1906) 4 Cal. App. 50, 87 Pac. 290 (complaint held not ambiguous or uncertain). The complaint in Abos v. Martyn (1939) 31 Cal. App. (2d) 705, 88 P. (2d) 797, vulnerable to a special demurrer, which defendant failed to interpose, was good as against the objection that it failed to state facts sufficient to constitute a cause of action, ibid. at $708,88 \mathrm{P}$. (2d) at 798 .

113 Dunn v. Dufficy (1924) 194 Cal. 383, 228 Pac. 1029. See Ragin v. Zimmerman (1929) 206 Cal. 723, 725, 276 Pac. 107 (X-ray used as aid to diagnosis).

114 Guilliams v. Hollywood Hospital (1941) 18 Cal. (2d) 97, 114 P. (2d) 1; (1941) 30 CarTr. L. REv. 96.

115 The demurrer was both general and special, "the grounds of special demurrer being uncertainty, ambiguity, and unintelligibility, with twenty-two specifications under each of these grounds". Supra note 113, at 385, 228 Pac. at 1030. 
The supreme court found that the allegations in Dunn v. Dufficy met the test of Smith $v$. Buttner. ${ }^{118}$ "Negligence may be charged in general terms; that is, what was done being stated, it is sufficient to say it was negligently done, without stating the particular omission which rendered the act negligent. But it must appear from the facts averred that the negligence caused or contributed to the injury."115 The court held in the Dunn case that the requirement of proximate cause was satisfied in the allegations of damage by reference therein to the prior allegations of negligence.

The general rule of the Dunn case is stated in the following language: "All that is required of a plaintiff, as a matter of pleading, ... is that his complaint set forth the essential facts of the case with reasonable precision and with sufficient particularity to acquaint the defendant with the nature, source, and extent of his cause of action." "118

In Guilliams v. Hollywood Hospital the supreme court reversed the lower court's action in sustaining a general and a special demurrer without leave to amend. During the plaintiff's sojourn in the hospital for a kidney operation and post-operative treatment a rib was broken in a manner unknown to the plaintiff, which injury was not discovered at the time or properly treated. The contention of the defendant was that the complaint "was fatally uncertain because it failed to specify the manner in which plaintiff's rib was broken or the acts of the defendant which were responsible for the injury."118

The holding of the Guilliams case may be summarized as follows:

1) The plaintiff may not recover on the bare statement that the defendant's negligence has caused him injury. Ordinarily the right to plead negligence in general terms means that the plaintiff must indicate the negligent acts or omissions. ${ }^{120}$

2) The particularity with which the cause of action should be stated is governed by the circumstances and the situation of the parties. ${ }^{121}$

3) There is no requirement that the plaintiff "identify and allege the precise moment of injury, or the exact nature of the wrong-

116 (1891) 90 Cal. 95, 27 Pac. 29.

117 Ibid. at 99, 100, 27 Pac. at 29.

118 Supra note 113, at 391, 228 Pac. at 1032.

119 Supra note 114, at 101, 114 P. (2d) at 4.

120 Ibid.

121 Ibid. 
ful act". Requirements of evidence and of pleading must be distinguished. ${ }^{122}$

The supreme court, however, did not hold in the Guilliams case that the complaint was sufficient as against a special demurrer, but did declare that "it was a manifest abuse of discretion to sustain the special demurrer without leave to amend where the plaintiff can amend his pleadings to state a proper cause of action". ${ }^{123}$

It would appear, therefore, that in order to defeat a general demurrer the allegation of negligence in inalpractice cases does not require a detailed statement of how or why a specific act is negligent. But some act or omission should be alleged. If the defendant desires greater specification and files a special demurrer, it would, according to the Guilliams case holding, constitute reversible error to sustain such special demurrer without leave to amend if the plaintiff can do so. There would appear to be little advantage to the plaintiff in pleading how or why an act or omission is negligent.

b. Example of pleading negligence in general terms; specification that defeats res ipsa loquitur: In Armstrong v. Wallace ${ }^{124}$ one of the questions decided on appeal was that the language of the complamt did not allege specific acts of negligence. The application of the doctrine of res ipsa loquitur was therefore not defeated. ${ }^{125}$ The paragraph in the complaint charging negligence read as follows:

"That the defendant Carl T. Wallace then and there and during the said operation, negligently and carelessly deposited and left an abdominal sponge or gauze pad within the abdomen of said Maxine Armstrong. That the said Carl T. Wallace negligently and carelessly closed said incision and sutured the same without first removing said abdominal sponge or gauze pad which he had theretofore deposited and left within the abdomen of said plaintiff Maxine Armstrong." 120

In speaking of the foregoing allegations the court declared that they "at most merely charge that appellant negligently left a sponge in the abdomen of the plaintiff. No attempt was made to describe

122 Ibid. at 102,114 P. (2d) at 4.

123 Ibid. at 104, 114 P. (2d) at 5.

123 Ibid. at 104, 114 P. (2d) at 5.

124 (1935) 8 Cal. App. (2d) 429, 437, 47 P. (2d) 740, 744. The Armstrong case holding on the question of pleading that defeats the operation of res ipsa loquitur is cited with approval in Ales v. Ryan (1936) 8 Cal. (2d) 82, 93, 64 P. (2d) 409, 414.

125 See infra note 175 .

128 Supra note 124 , at 437,47 P. (2d) 740 , at 744. 
the negligence in detail nor charge why or under what circumstances it occurred. Such an allegation is analogous to a complaint of an injury by a guest in an automobile who alleges that the operator so negligently and carelessly drove and operated the car as to strike an obstruction, causing the injury complained of, or of a brick falling from a building upon a passerby below, inflicting damage." "127

The language of the California cases is not always consistent. The law is in some doubt with reference to what constitutes adequate pleading of proximate cause. ${ }^{128}$

c. Joinder of parties. The case of Kraft $v$. Smith ${ }^{120}$ establishes the law in California as permitting the joinder of separate tort feasors as defendants in a malpractice action. Under sections $379 a, 379 b$, and $379 \mathrm{c}$ of the Code of Civil Procedure a great latitude in joining parties defendant is possible. ${ }^{130}$ Section 427 of the Code of Civil Procedure does not operate to restrict the power there given, which is

127 Ibid. See infra note 175 for pleading of negligence in res ipsa loguitur cases.

128 Rannard v. Lockheed Aircraft Corp. (March 20, 1945) 26 A.C. 67, 157 P. (2d) 1, appears to this writer to extend surprisingly the rules for the pleading of negligence in general terms heretofore recognized in California. According to the California Supreme Court decision in the Rannard case all that now appears to be necessary is to allege ( 1 ) negligence with respect to a stage or stages (note that a "stage in medical services rendered" is not a single, separate act but many acts) in the rendering of medical services and (2) that "as a direct and proximate consequence and result" of the negligence the plaintiff sustained damage. (Ibid. at $75,157 \mathrm{P}$. (2d) at 5.) No fact showing proximate cause need be alleged. (See Smith v. Buttner (1891) $90 \mathrm{Cal} .95,100,27$ Pac. 29.) Lang v. Lilley \& Thurston Co. (1912) 20 Cal. App. 264, 266, 128 Pac. 1931, declared: "It is not sufficient to allege that the elevator was negligently operated and thereby the injury was produced." The Rannard case (ibid. at 75, 157 P. (2d) at 5) appears to overrule this language in the Lang case. A careful analysis of the actual language of the pleadings in leading cases in California on the plending of negligence in general terms will reveal some more or less specific factual allegation showing proximate cause. Such a factual allegation is missing in the Ramnard case. The district court of appeal opinion in the judgment of this writer accurately expresses what has been regarded as the requirements of pleading negligence in general terms. (150 P. (2d) $255,257,258$.)

129 (1944) 24 Cal. (2d) 124, 148 P. (2d) 23.

130 See Smith v. Coleman (1941) 46 Cal. App. (2d) 507, 512, 513, 116 P. (2d) 133, 136 , which involved plaintiff's rights in a workman's compensation situation. Although a release had been given by the plaintif releasing the employer, insurance company, and their physicians and surgeons "from all claims, demands, actions, or causes of action of any kind whatsoever, on account of, or by rcason of the injury" sustained in the course of employment, the court declared: "But where, as in the instant case, recovery for the new or aggravated injury which resulted from the negligence of the physician who treated plaintiff's industrial injury is sought against the physician only, and neither the employer nor the latter's insurance carrier is a party, plaintiff may recover in an ordinary civil action for malpractice." (Italics added.) See Ash v. Mortensen (1944) 24 Cal. (2d) 654, $150 \mathrm{P}$. (2d) 876 (the rule that the release of the original wrongdoer releases the attending doctor from liability for malpractice is not applicable in California). 
"available upon a showing either that negligence of two or more persons, whether joint, independently concurrent, or successive, contributed proximately to cause the injury for which recovery is sought, or that the injury for which recovery is sought was proximately caused by the negligence of one or another or several of two or more persons and, as to each person who is not charged absolutely, that a reasonable uncertainty, requiring determination of some factual or legal issue, exists in respect to alternative or quantitative liability." $" 131$

In order to avail himself of the protection of section $379 \mathrm{c}$ of the Code of Civil Procedure the plaintiff should plead doubt as to the person from whom to seek redress..$^{132}$

d. Methods of proof. Four types of situations commonly recur in which recovery for malpractice has been allowed. The following classification is based upon the nature or the method of proof required to carry the case to the jury. If the facts of a particular case will not bring it within any of the following groups, it would appear that no recovery can be expected:

1) negligence established only by competent expert testimony;

2) negligence established by the expert testimony of the defendant (section 2055 Code of Civil Procedure);

3) negligence established in the absence of expert testimony;

4) negligence established prima facie by res ipsa loquitur.

The situation which occurs most often is that in which expert testimony is required, group 1 . But recent decisions indicate an increasing willingness to allow recovery when the facts may be viewed so as to meet the requirements of groups 2,3 , or 4 .

e. Expert testimony. Expert testimony is required when it is necessary to establish what the usual or customary practices as regards diagnosis and treatment are in the community where the injury was sustained. ${ }^{133}$ The judge determines the competency of the expert, and a clear abuse of discretion must be shown, or an actual want of

131 Supra note 129, at 130, 131, 148 P. (2d) at 26.

132 Ibid. at 132, 148 P. (2d) at 27.

133 Engelking v. Carlson (1939) 13 Cal. (2d) 216, 88 P. (2d) 695. The reason for the rule is given in Arais v. Kalensnikoff (1937) $10 \mathrm{Cal}$. (2d) 428, 433, 74 P. (2d) 1043, 1047: "Only physicians who practice their profession at a particular place could have any knowledge of the method of treatment customarily used by the other members of the profession practicing there; the subject, therefore, calls for expert opinion only. But the testimony of an expert in such a case is not conclusive in the sense that it must be accepted as true .... It is conclusive, however, to the extent that it may not be contradicted by the testimony of a non-expert witness." 
evidence appear, in order to overthrow the judge's ruling on competency. ${ }^{13 s}$

f. Examples showing when expert testimony has been required. Expert testimony has been held necessary to establish the plaintiff's case in the following instances, selected to give an indication of the comprehensive scope of the general rule: tooth extraction: charge of negligence as to failure to visit plaintiff at her home and to give further or different treatment; ${ }^{135}$ injury to nerve in operation to correct instability in left knee; ${ }^{138}$ treatment of broken arm: charge of negligence as to failure to take X-ray pictures frequently, to correct angulation of union, to maintain traction and cast on arm-case involved specialist in a metropolitan community; ${ }^{137}$ removal of a hypodermic needle which had broken in left thigh; ${ }^{138}$ alleged mistake in diagnosis of nature of foreign body in eye ${ }^{139}$ death from septicemia froin a carbuncle; ${ }^{140}$ alleged improper reduction and treatment of broken leg-case involved practice in a rural community; ${ }^{141}$ alleged improper prescribing of remedy known as phanadorn; ${ }^{142}$ alleged inproper injection of saline solution containing more than normal glucose content after appendectony; ${ }^{143}$ alleged negligence in nraking incorrect diaguosis of pregnancy. ${ }^{144}$

g. Testimony of defendant under section 2055 Code of Civil Procedure. The case of Lawless $v$. Calaway ${ }^{145}$ states clearly the rights which the plaintiff in a malpractice suit has under section 2055 of the Code of Civil Procedure. Section 2055 provides that the adverse party in a civil suit or proceeding may be examined "as if under crossexamination". The court in Lawless $v$. Calaway cites with approval language from Langford $v$. Issenhuth ${ }^{146}$ to the effect that such an adverse witness may be called to prove "a single material fact or a

134 Mirich v. Balsinger (1942) 53 Cal. App. (2d) 103, 114, 127 P. (2d) 639, 644.

135 Rising v. Veatch (1931) $117 \mathrm{Cal}$. App. 404, 408, 409, 3 P. (2d) 1023, 1025. See an important annotation on this subject: (1942) 141 A. L. R. 5-50.

138 Engelking v. Carlson (1939) 13 Cal. (2d) 216, 221, 88 P. (2d) 695, 698.

13r' Sansom v. Ross-Loos Medical Group (1943) 57 Cal. App. (2d) 549, 134 P. (2d) 927 .

138 Keister v. O'Neil (1943) 59 Cal. App. (2d) 428, 436, 138 P. (2d) 723, 728.

139 Adams v. Boyce (1940) 37 Cal. App. (2d) 541, 550, 99 P. (2d) 1044, 1049.

140 Ross v. Hieronymus (1934) 2 Cal. App. (2d) 258, 37 P. (2d) 837.

141 Bickford v. Lawson (1938) 27 Cal. App. (2d) 416, 81 P. (2d) 216.

142 Taylor v. Fishbaugh (1938) 26 Cal. App. (2d) 300, 79 P. (2d) 174.

143 Callahan v. Hahnemann Hospital (1934) 1 Cal. (2d) 447, 35 P. (2d) 536.

144 Patterson v. Marcus (1928) 203 Cal. 550, 265 Pac. 222.

145 (1944) 24 Cal. (2d) 81, 147 P. (2d) 604.

146 (1912) 28 S. D. $451,460,134$ N. W. $889,892$. 
number of material facts, even the whole case"147 of the party using the adverse witness.

Lawless v. Calaway is authority for the following propositions:

1) In a malpractice suit the plaintiff can establish his case by the testimony of the defendant. ${ }^{148}$

2) If the plaintiff's case is one that must be established by expert testimony, an examination under section 2055 of the defendant will satisfy this requirement, and the interrogation should not be limited so as to prevent eliciting essential expert testimony. ${ }^{140}$

3) If the trial court refuses to permit interrogation of the defandant as an expert witness by the plaintiff, "an offer of proof is not a prerequisite to arguing on appeal the prejudicial nature of the exclusion of such evidence".150

Crowe v. McBride ${ }^{151}$ decided in Nov. 1944, applies the rule that in considering the propriety of a non-suit, when the defendant has been called under section 2055 of the Cide of Civil Procedure, the testimony of the defendant "is to be treated as evidence in the case in so far as it is favorable to plauitiffs". 152

Lashley v. Koerber, ${ }^{153}$ decided Feb. 20, 1945, reaffirms the Lawless rule as follows: "The expert testimony which establishes plaintiff's prima facie case in a malpractice action may be that of defendant." (Italics added). The Lashley case declares further that "extra-judicial admissions of defendant have the same legal coin-

147 Supra note 145 , at 90, 147 P. (2d) at 609.

148 Ibid. See Anderson v. Stump (1941) 42 Cal. App. (2d) 761, 765, 109 P. (2d) $1027,1030$.

149 Supra note 145 , at $91,92,147$ P. (2d) at 609 . The court specifically refuses to recognize the authority of contra cases.

150 Ibid.

15125 A. C. 292, 293, 153 P. (2d) 727, 727. The injury was caused by the "explosion" of an electric therapeutic light bulb while the plaintiff, who suffered from arthritis and neuritig, had her bare back exposed to the light, placed about two and one-half feet above her. The testimony of the defendant "shows that little if any inspection was made of the bulb", ibid. at 294, 153 P. (2d) at 728, and indicated that after the accident screens were used as a protective measure, ibid. at 295, 153 P. (2d) at 728. The court does not consider the doctrine of res ipsa loquitur in reversing the judgment of non-suit.

152 Supra note 151 , at 293,153 P. (2d) at 727.

15326 A. C. 1,156 P. (2d) 441.

104 Ibid. at 7, 156 P. (2d) 444. 
petency as direct expert testimony to establish the critical averments of the complaint", ${ }^{155}$ following Scott v. Sciaroni. ${ }^{156}$

h. Proof of negligence without expert testimony. If the defendant's negligence may be established without the presentation of expert testimony, the facts may permit of the application of the doctrime of res ipsa loquitur. But not every non-expert testimony case is a res ipsa loquitur case, although there is no very sharp distimction inade between non-expert testimony cases that are res ipsa loquitur cases and those which are not. It is clear, however, that under certain conditions the plaintiff, unaided by res ipsa loquitur or expert testimony, may still go to the jury on his evidence. Various formulae, not always mutually exclusive, have been laid down as indicative of these conditions.

Expert testimony has, for instance, been held not to be required in the following situations:

1) "when the question of the propriety of the treatment is so well known or simple as to be a matter of common knowledge"; $;$ 15r

2) when the negligence "is of such a nature as may be ascertained by the ordinary use of the senses of a non-expert"; ${ }^{15 s}$

3) when the negligence results in mjury to an undiseased portion of plaintiff's body; ${ }^{159}$

4) where the court takes judicial notice of the necessity of a certain method of treatment or of precautions that are required to prevent infection or of other medical or biological facts. ${ }^{160}$

155 Ibid., 156 P. (2d) 444.

156 (1924) 66 Cal. App. 577, 583, 584, 226 Pac. 827, 830.

157 Rising v. Veatch (1931) 117 Cal. App. 404, 408, 3 P. (2d) 1023, 1024; Mastro v. Kennedy (1943) 57 Cal. App. (2d) 499, 134 P. (2d) 865 (unsterile instrument used and operative field not properly sterilized).

158 Rising v. Veatch, supra, note 157. Nelson v. Painless Parker (1930) 104 Cal. App. 770, 776, 286 P. 1078, 1081 (dropping tooth after extraction into patient's lungs or bronchial tubes).

150 Morrison v. Lane (1935) 10 Cal. App. (2d) 634, 635, 52 P. (2d) 530, (chiropractor fractured 12th rib of plaintiff complaining of pains in her face); Thomsen $\mathrm{v}$. Burgeson (1938) 26 Cal. App. (2d) 235, 79 P. (2d) 136 (removal of plaintiff's uvula and portion of soft palate in a tonsillectomy).

100 Inderbitzen v. Lane Hospital (1932) 124 Cal. App. 462, 467, 12 P. (2d) 744, 747 , ("We will likewise take judicial knowledge of the danger of infection to a woman about to give birth to a child from a vaginal examination performed with unsterilized hands.") ; Barham v. Widing (1930) 210 Cal. 206, 216, 291 Pac. 173, 177, ("It was not necessary for any dentist or physician to state that the conduct of the defendant was 
On demal of a hearing in Wires $v$. Litle ${ }^{161}$ the supreme court said: "Such denial is not to be taken as indicating approval by this court of the discussion concerning matters of common knowledge which, it is said, a jury may properly consider in an action for malpractice."162 Justice Houser in a separate opinion concurring with the denial order but dissenting from the majority's reservation of approval identified the language not approved to be the following:

"It might be well argued that it is a matter of common knowledge that a needle accidentally imbedded in the finger of a seamstress might cause infection if not promptly extracted; that a clear X-ray picture would be of assistance to the surgeon; and that if an indistinct picture be secured from a dental office an effort should be made to secure a clear picture from those equipped with apparatus for that purpose."

The court's disapproval of the above language has never been expressly withdrawn.

The present state of the law would appear to be still unsettledperhaps in the nature of things necessarily unsettled-as to the point where common knowledge stops and expert knowledge commences; and thus the plaintiff will do well to rest his case, if the facts permit, on expert testimony, on the defendant's testimony as an adverse party, or on res ipsa loquitur.

i. Res ipsa loquitur. The trial court in the case of Ybarra v. Span$\operatorname{gard}^{164}$ entered a judgment of non-suit against all the defendants because the plaintiff, who had undergone an appendectomy, could not tell by what individual's negligence or by what instrumentality he had sustained a shoulder injury while under an anaesthetic at the hospital. The plaintiff's plight is well expressed in the language of the District Court of Appeal, which refused to recognize the doctrine of res ipsa loquitur: "Granting that something happened to the plaintiff between the sunset and the sunrise of his consciousness, who caused it is veiled in the darkness of an utter lack of evidence."165

negligent or in conflict with the usual established practice of the profession in that vicinity to administer a local anaesthetic for the purpose of extracting a tooth without sterilizing the needle, or the flesh into which it was inserted. The court will take judicial notice of the necessity to use ordinary care to procure sterilization under such circunstances.") See Thomsen v. Burgeson, suppra note 159.

161 (1938) 27 Cal. App. (2d) 240, 80 P. (2d) 1010.

$162 \mathrm{Ibid}$, at $244,245,82 \mathrm{P}$. (2d) $388,388,389$.

$163 \mathrm{Ibid}$, at 249, 250, 82 P. (2d) 388, 389.

104 (Dec. 27, 1944) 25 A. C. 479,154 P. (2d) 687.

105 (Mar. 1944) 146 P. (2d) 982, 983. 
The supreme court in Ybarra v. Spangard specifically holds: "Where a plaintiff receives unusual injuries while unconscious and in the course of medical treatment, all those defendants who had any control over his body or the instrumentalities which might have caused the mjuries may properly be called upon to meet the inference of negligence by giving an explanation of the accident."166

The case is significant because it extends and enlarges the traditional application of the basic concepts in res ipsa loquitur to malpractice situations. ${ }^{167}$ Ybarra $v$. Spangard, notwithstanding the court's express reservation as to the scope of the decision's applicability, ${ }^{168}$ is highly persuasive authority for the following propositions:

1) The basic underlying purpose of the res ipsa loquitur doctrine should determine its application in a particular case rather than the limitations of a rigidly expressed legal formula. ${ }^{100}$

2) The number or relationship of the defendants does not alone determine the applicability of res ipsa loquitur. ${ }^{170}$

3) An unconscious person in a hospital is not required to show more than injury from an external force in order to invoke res ipsa loquitur against all those who might have negligently caused it. ${ }^{171}$

4) The right of control of the instrumentality inflicting harm rather than actual control fulfils the "control" condition of res ipsa loquitur in malpractice cases. ${ }^{172}$

It should be borne in mind that two facts strongly influenced the court in the Ybarra v. Spangard holding: 1) the occurrence of the imjury while the patient was unconscious, ${ }^{173} 2$ ) "the distinct ijjury to a healthy part of the body not the subject of treatment". ${ }^{174}$ In any malpractice case containing these two factors the Ybarra decision would appear clearly controlling. ${ }^{175}$

166 Supra note 164, at 486, 154 P. (2d) at 691.

167 Ibid. at 481,154 P. (2d) at 689.

168 Ibid. at 486,154 P. (2d) at 691.

$160 \mathrm{lbid}$. at $482,154 \mathrm{P}$. (2d) at 689.

170 Ibid. at 484,154 P. (2d) at 690 .

171 Ibid. at 485,154 P. (2d) at $690,691$.

172 Ibid. at 485,154 P. (2d) at 691.

173 This fact removes any doubt as to the injury occurring as the result of any voluntary action on the part of the plaintiff.

104 Supra note 164 , at 483,154 P. (2d) at 690.

175 It has been held that when the plaintiff sets out specifically the negligent acts or omissions complained of, the doctrine of res ipsa loquitur is not applicable, Connor 
j. Instances when res ipsa loquitur applied. The doctrine of res ipsa loquitur has been applied or held applicable in the following instances, among others: burns from infra-red lamp used in treatment while patient under opiates; ${ }^{176}$ burns from X-ray machine used in diagnosis; ${ }^{177}$ leaving a large laparotomy sponge in abdomen after operation; ${ }^{178}$ knocking out tooth while patient under anaesthetic for removal of tonsils; ${ }^{170}$ burns from hot water bottle while patient unconscious following a Caesarean operation. ${ }^{150}$

k. Instances when res ipsa loquitur held not applicable. The doctrime of res ipsa loquitur has been denied application in the following instances, among others: injection of alcohol into sciatic nerve; ${ }^{181}$ loss of testicle after operation where all expert testimony showed at

v. Atchison, Topeka \& Santa Fe Railway Co. (1922) 189 Cal. 1, 5, 207 Pac. 378, 379; Davidson v. American Liquid Gas Corp (1939) 32 Cal. App. (2d) 382, 89 P. (2d) 1103 (form of complaint held not to prevent res ipsa loquitur, but plaintiff called witnesses to establish negligent acts-hence res ipsa loquitur not applicable); Leet v. Union Pac. R. R. Co. (Dec. 30, 1944) 25 A. C. 764, 775-780, 155 P. (2d) 42, reh'g. den., discusses at length the problems of pleading and proving negligence in so far as the doctrine of res ipsa loquitur is concerned. The Davidson case herewith cited is superseded by the holding in the Leet case. The Leet case makes two significant changes in the previous rules governing pleading and proof of res ipsa loquitur negligence cases: 1) wlien negligence is pleaded both generally and specifically the plaintiff is not limited to particular acts of negligence alleged in showing a res ipsa loquitur situation ("It must be concluded therefore that if plaintiff alleges negligence specifically and generally he may rely upon the doctrine and the general inference of neglignce flowing therefrom without limitation to the particular acts of negligence alleged inasmuch as by the general allegation of negligence defendant is notified that lie must meet such a broad inference." Ibid. at $777,778,155$ P. (2d) at 50);2) proof of specific acts of negligence will not alone if the situation is otherwise proper prevent application of res ipsa loquitur ("If, because of the circumstances of the case and the probabilities, an inference of negligence is raised, the doctrine should be applied, it is difficult to see wly its application should be denied merely because plaintiff proves specific acts of negligence. There is no reason why such proof should wholly dispel the inference any more than it would in any other case. ... Hence we conclude that evidence of specific acts of negligence does not deprive plaintiff of the benefit of the doctrine, unless the case is one where the inference would be dispelled as a matter of law under the same rules that apply in cases generally." Ibid. at $779,780,155$ P. (2d) at 51).

176 McCullough v. Langer (1937) $23 \mathrm{Cal}$. App. (2d). 510, 518,·73 P. (2d) 649, 653.

172 Moore v. Steen (1929) 102 Cal. App. 723, 727, 283 Pac. 833, 835; see also Ragin v. Zimmerman (1929) 206 Cal. 723, 729, 276 Pac. 107, 109.

178 Ales v. Ryan (1936) 8 Cal. (2d) 82, 93, 64 P. (2d) 409, 414; see also Key v. Caldwell (1940) 39 Cal. App. (2d) 698, 702, 104 P. (2d) 87, 89; also Armstrong v. Wallace (1935) 8 Cal. App. (2d) 429, 435, 47 P. (2d) 740, 743.

179 Brown v. Shortlidge (1929) 98 Cal. App. 352, 354, 355, 277 Pac. 134, 135.

180 Timbrell v. Suburban Hospital (1935) 4 Cal. (2d) 68, 71, 47 P. (2d) 737, 739.

See also Meyer v. McNutt Hospital (1916) 173 Cal. 156, 159; 159 Pac. 436, 437. 181 Donahoo v. Lovas (1930) 105 Cal. App. 705, 709, 288 Pac. 698, 700. 
most an error of judgment; ${ }^{182}$ severance of nerve during operation where plaintiff unconscious and untoward result does not ordinarily occur in such an operation; ${ }^{183}$ incorrect diagnosis of foreign body in eye ${ }^{184}$ burns to ankle in diathermy for arthritis ${ }^{185}$ (where defendant's testimony as to standard of care is available and there is a conflict in evidence as to whether such standard was observed).

1. Evidential weight of res ipsa loquitur. The evidential weight of res ipsa loquitur in California is clearly stated in the following passage from Ales $v$. Ryan: ${ }^{186}$

"The rule is well settled by a multitude of decisions of the appellate courts of this state to the effect that the inference of negligence which is created by the rule res ipsa loquitur is in itself evidence which may not be disregarded by the jury and which in the absence of any other evidence as to negligence, necessitates a verdict in favor of the plaintiff.

"It is incumbent on the defendant to rebut the prima facie case so created by showing that he used the care required of him under the circumstances. The burden is cast upon the defendant to meet or overcome the prima facie case made against him. The defendant is not required to establish his defense by a preponderance of the evidence. All that is required is that he produce evidence which equals in evidentiary weight the inference which the doctrine creates

182 Nicholas v. Jacobson (1931) 113 Cal. App. 382, 385, 298 Pac. 505, 506.

183 Engleking v. Carlson (1939) 13 Cal. (2d) 216, 220, 88 P. (2d) 695, 697. "To say that the doctrine of res ipsc loquitur allows the recovery of damages in every case where an injury does not ordinarily occur would place a burden upon the medical profession which the law has not heretofore laid upon it. Moreover, such a rule is not justified by either reason or authority. The law has never held a physician or surgeon liable for every untoward result which may occur in medical practice."

184 Adams v. Boyce (1940) 37 Cal. App. (2d) 541, 551, 99 P. (2d) 1044.

185 Trindle v. Wheeler (1943) 23 Cal. (2d) 330, 335, 143 P. (2d) 932, 934. Plaintiff "was entitled to rely upon the expert testimony which had been introduced by the defendant; and in the absence of any such testimony offered by the plaintiff the court, on motion for a directed verdict, was required to consider tbe evidence favorable to the plaintiff introduced by the defendant. On the question of the prevailing standard of care, therefore, it may be said there was no conflict, and the standard establisbed by the defendant's witnesses was a proper guide for the court. But on the question of whether that standard of care was followed, there was a direct and substantial conflict in the evidence. ... The plaintiff invokes the doctrine of res ipse loquitur, but it is unnecessary to decide whether it is or is not applicable under the facts of tbis case. Even if we assume that a burn does not usually result from careful treatment, the benefit of the permissible inference is not necessary in support of her case."

186 (1936) 8 Cal. (2d) 82, 64 P. (2d) 409. See Druzanich v. Criley (1942) $19 \mathrm{Cal}$. (2d) 439,445 , quoting with approval from Ales v. Ryan passage (first three sentences here given). The illogicality of the California view that inferences are evidence has been powerfully attacked. See (1936) 26 CALrF. L. REv. 519, (1942) 31 ibid. 108. 
in favor of plaintiff. The burden of proof as generally understood never shifts from the plaintiff to the defendant on the general issue of negligence. The inference of negligence unrebutted is actionable negligence coming within the doctrine of res ipsa loquitur and is sufficient to support a verdict for the plaintiff." 187

m. Hypothetical question. When the establishment of the plamtiff's case depends upon expert testimony, the use of the hypothetical question is a highly practical device for presenting the plaintiff's theory of the case to the jury. The California cases support the following propositions concerning the use and effect of a hypothetical question answered by a duly qualified expert:

1) The answer of the expert that the care or treatment set forth in the question was not up to the standard of care and skill in the community where the alleged negligence occurred makes a prima facie case for the jury, and cross examination and conflicting evidence of defendant's witnesses raise only questions of credibility. ${ }^{188}$

2) The expert is not required to give the reasons for his answers if he is not asked for them, and although his evidence is the only evidence as to whether the defendant used such ordimary care as would be used by doctors possessing ordinary skill in the community where the injury occurred, it is error for the trial court to grant defendant's motion for a new trial. ${ }^{180}$

3) The testimony of an expert witness who has not seen the plaintiff in answer to a hypothetical question is sufficient to support a finding contrary to all the testimony of other medical witnesses who have seen and examined the patient. ${ }^{190}$

4) A hypothetical question may be framed upon the theory of the questioning party, and need not include a statement of all of the evidence in the case. ${ }^{101}$

1878 Cal. (2d) at 99, 64 P. (2d) at 417.

188 Lewis v. Johnson (1939) 12 Cal. (2d) 558, 560, 86 P. (2d) 99, 100, 101.

180 Thomason v. Hethcock (1935) 7 Cal. App. (2d) 634, 640, 46 P. (2d) $832,835$.

100 Sales v. Bacigalupi (1941) 47 Cal. App. (2d) 82, 86, 117 P. (2d) 399, 402, hearing den.

191 Mirich v. Balsinger (1942) 53 Cal. App. (2d) 103, 117, 127 P. (2d) 639, 646, hearing den.; Coyne v. Pacific Mutual Life Insurance Co. (1935) 8 Cal. App. (2d) 104, 111, 112, 47 P. (2d) 1079, 1082, kearing den.; Forbis v. Holzman (1936) 5 Cal. (2d) 407, $410,411,55$ P. (2d) 201, 202, 203. See the language in Bickford v. Lawson (1938) 27 Cal. App. (2d) 416, 428, 81 P. (2d) 216, 222: "Where the facts related in the hypothetical question omit material undisputed evidence necessary to a fair, intelligent and sound opinion of the witness regarding the problem to be determined, it is not error 
5) The fact that the opinion of the expert is not based on all the evidence goes only to its weight, not to its competency or materiality. ${ }^{192}$

6) The opinion of the expert may be based upon the result of recovery, and the jury may make a finding of negligence on such expert testimony. ${ }^{193}$

7) The hypothetical question must be phrased in such a way as to refer to a hypothetical doctor, and not the defendant; otherwise there is a technical invasion of the jury's field. ${ }^{104}$

8) It is error to require an unqualified "yes" or "no" answer to a hypothetical question by an expert witness, when the witness is unable honestly or conscientiously to make such an unquahfied answer. ${ }^{105}$

n. Sustaining the burden of proof. In order to establish the negligence of the defendant physician or dentist in a malpractice suit, it is not necessary to prove the failure of the physician or dentist to attain the required standard of care conclusively or beyond the possibility of a doubt. The recent cases adopt the view expressed in

for the court to sustain an objection thereto. The chief test of the competency of a hypothetical question which seeks to elicit the professional opinion of a physician regarding the treatment of a patient is whether it is a full and fair recital of all the essential evidence disclosed by the record on the particular issue which is involved. Where the question assumes facts in direct conflict with the undisputed evidence, or omits material facts upon which a determination of the problem depends, the hypothetical question becomes misleading and it is then likely to lead the witness to a false conciusion, and should be rejected."

Justice Traynor, for the court majority in People v. Wilson (1944) 25 A. C. 337, $344,345,153$ P. (2d) $720,724,725$, makes the following observations on hypothetical questious: "The method of obtaining opinion evidence from an expert by hypothetical questions is unsatisfactory ...., but it is at present the least objectionable known to the law. The trial court, however, should prevent the use of misleading or unfair hypothetical questions, permitting only questions that sufficiently specify the assumptions on which they are based and contain only such assumptions as do not contradict the weight of the evidence in the case. . . . While each hypothesis contained in the question should have some evidence to support it, it is not necessary that the question include a statement of all the evidence in the case. The statement may assume facts within the limits of the evidence, not unfairly assembled, upon which the opimion of the expert is required, and considerable latitude must be allowed in the choice of facts as to the basis upon which to frame a hypothetical question. ... There is no hard and fast rule that the expert cannot be asked a question that coincides with the ultimate issue in the case."

192 Mirich v. Balsinger, supra note 191, at 117,127 P. (2d) at 646.

193 Ibid. at 117,127 P. (2d) at 646 .

194 Criss v. Angelus Hospital Ass'n (1936) 13 Cal. App. (2d) 412, 415, 416, 417, 56

P. (2d) 1274, 1275, 1276, 1277, hearing den.

195 McGuire v. Baird (1937) 9 Cal. (2d) 353, 355, 70 P. (2d) 915, 916. 
Dimock v. Miller: ${ }^{196}$ "If . . it is necessary to demonstrate conclusively and beyond the possibility of a doubt that the negligence resulted in the injury, it would never be possible to recover im a case of negligence in the practice of a profession which is not an exact science." The rule that "substantial evidence which reasonably supports the judgment is sufficient"198 prevails. $^{199}$

o. Statute of limitations. A malpractice action sounds in tort, ${ }^{200}$ and section 340, subdivision 3 of the Code of Civil Procedure ordinarily bars an action if commenced more than one year after the date

198 (1927) 202 Cal. 668, 262 Pac. 311.

197 Ibid. at 671, 262 Pac. at 312.

198 Mirich v. Balsinger (1942) 53 Cal. App. (2d) 103, 114, 127 P. (2d) 639, 644. The following language from the same case on the same page indicates the practical application of the rule: "It is therefore not required in the trial of such cases (malpractice cases) that the negligence of the defendant as the proximate cause of the injury he established with such absolute certainty that any other conclusion is excluded." (Italics added.) See also Sansom v. Ross-Loos Medical Group (1943) 57 Cal. App. (2d) $549,553,134$ P. (2d) 927,930 : ". . . it is sufficient if there is substantial evidence which reasonably supports the judgment."

${ }^{199} \mathrm{~A}$ problem as to the sufficiency of evidence arises on appeal from a non-suit or a directed verdict for the defendant. Recent decisions of the supreme court have consistently reversed non-suits of lower-courts if res ipsa loquitur (Ybarra v. Spangard (1944) 25 A.C. 479, 486, 154 P. (2d) 687, 691) defendant's testimony under section 2055 C. C. P. (Crowe v. McBride (1944) 25 A. C. 292, 293, 153 P. (2d) 727, 727; Lawless v. Calaway (194i) 24 Cal. (2d) $81,89,90,91,147$ P. (2d) $604,608,609$ ), or extrajudicial admissions of defendant (Lashley v. Koerber (1945) 26 A. C. 1, 9, 156 P. (2d) 441,445 , tend substantially to support plaintiff's allegations of negligence.

Lawless v. Calaway is authority for the following propositions:

1) "Where ... an entire class of evidence has been declared inadmissible or the trial court has clearly intimated that it will receive no evidence of a particular type or class, or upon a particular issue, an offer of proof is not a prerequisite to arguing on appeal the prejudicial nature of the exclusion of such evidence." Ibid. at 91, 147, P. (2d) at 609. (Thompson v. Buffums', Inc. (1936) 17 Cal. App. (2d) 401, 405, 62 P. (2d) 171, 173, and In re Claire (1935) 9 Cal. App. (2d) $749,753,50$ P. (2d) 1070, 1072, are overruled on this point).

2) ". . . grounds not specified in a motion for non-suit will be considered by an appellate court only if it is clear that the defect is one which could not have been remedied had it been called to the attention of the plaintiff by the motion. This rule is complementary to the requirement that a party specify the grounds upon which his motion for nonsuit is based." Ibid. at 94, 147 P. (2d) at 610 for contra cases overruled).

See Contreras v. Gumming (1942) 54 Cal. App. (2d) 421 , 129 P. (2d) 18, where non-suit was improperly granted when autopsy revealed that death was due to chromic myocarditis and questions as to whether alleged inalpractice might have had a detrimental effect on the heart were excluded.

$200 \mathrm{~A}$ malpractice action abates with defendant physician's death and does not survive against his estate, Speer v. Brown (1938) 26 Cal. App. (2d) 283, 79 P. (2d) 179. 
of the injury, i. e. one year after the "wrongful act or neglect" causing the injury. ${ }^{201}$

The following analytic table of leading California cases indicates the circumstances considered when the one year period of the statute of limitations begins to run:

\begin{tabular}{|c|c|c|c|c|c|}
\hline CASE NAMRE & $\begin{array}{l}\text { DATE AND NATULE } \\
\text { OF WRONGFUI ACT }\end{array}$ & $\begin{array}{l}\text { DATE } \\
\text { TIEATATENI } \\
\text { STOPPED } \\
\text { OR BLLATION- } \\
\text { SHIP CEASPAD }\end{array}$ & $\begin{array}{l}\text { DATE OP } \\
\text { DISCOVERY } \\
\text { OF WRONG- } \\
\text { PUL, ACT }\end{array}$ & $\begin{array}{l}\text { DATR } \\
\text { OP SUIT }\end{array}$ & $\begin{array}{l}\text { IS ONE YRAT } \\
\text { PERIOD } \\
\text { PROME DATS } \\
\text { OF INJURY } \\
\text { ILTOSED? }\end{array}$ \\
\hline Wetzel v.Pius 202 & $\begin{array}{l}\text { May } 17,1922 \\
\text { Improper setting } \\
\text { of fractured femur }\end{array}$ & Feb., 1923. & & $\begin{array}{l}\text { Aug. 16, } \\
1923 .\end{array}$ & YES \\
\hline $\begin{array}{l}\text { Gum. v. Allen } 203 \\
\text { (overruled by } \\
\text { Huysman } v . \\
\text { Kirsch) }\end{array}$ & $\begin{array}{l}\text { Operation more than } \\
\text { year before suit }\end{array}$ & $\begin{array}{l}\text { Four mos. } \\
\text { before } \\
\text { suit. }\end{array}$ & $\begin{array}{l}1 \text { month } \\
\text { hefore } \\
\text { suit. }\end{array}$ & & YES \\
\hline $\begin{array}{l}\text { Huysman v. } \\
\text { Kirsch } 204\end{array}$ & $\begin{array}{l}\text { Jan. } 3,1931 \\
\text { Drainage tube } \\
\text { left in abdomen }\end{array}$ & $\begin{array}{l}\text { Dec. 12, } \\
1932 .\end{array}$ & $\begin{array}{l}\text { Sept. 26, } \\
1932 .\end{array}$ & $\begin{array}{l}\text { Jan. 7, } \\
1933 .\end{array}$ & NO \\
\hline $\begin{array}{l}\text { Trombley } v . \\
\text { Kolts } 205\end{array}$ & $\begin{array}{l}\text { Feb. } 12,1932 \\
\text { Skin clip left in } \\
\text { body after } \\
\text { operation }\end{array}$ & $\begin{array}{l}\text { Sept., } \\
1934 .\end{array}$ & $\begin{array}{l}\text { about } \\
\text { Nov., } \\
1932 \text {. }\end{array}$ & $\begin{array}{l}\text { Feb. 1, } \\
1935 .\end{array}$ & NO \\
\hline $\begin{array}{l}\text { Petrucci v. } \\
\text { Heidenreich200 }\end{array}$ & $\begin{array}{l}\text { July } 25,1937 \\
\text { Cervical cauteriza- } \\
\text { tion of uterus }\end{array}$ & $\begin{array}{l}\text { April 1, } \\
1939 .\end{array}$ & & $\begin{array}{l}\text { Oct. 20, } \\
1939 .\end{array}$ & NO \\
\hline $\begin{array}{l}\text { Ehlen v. } \\
\text { Burrows20r. }\end{array}$ & $\begin{array}{l}\text { Prior to Aug. 2, } 1939 \\
\text { Broken roots of } \\
\text { teeth not removed }\end{array}$ & $\begin{array}{l}\text { Not later } \\
\text { than Aug. } \\
2,1939 \text {. }\end{array}$ & $\begin{array}{l}\text { In Jan., } \\
1940, \text { or } \\
\text { before } \\
\text { Feb. 21, } \\
1940 .\end{array}$ & $\begin{array}{l}\text { Jan. 18, } \\
1941 .\end{array}$ & NO \\
\hline $\begin{array}{l}\text { Faith v. } \\
\text { Erhart20s }\end{array}$ & $\begin{array}{l}\text { After Aug. } 15,1930 \\
\text { (withim } 4 \text { mos.) } \\
\text { teeth roots } \\
\text { left in jaw }\end{array}$ & $\begin{array}{l}\text { Approx. } \\
4 \text { mos. after } \\
\text { Aug. 15, } \\
1930 .\end{array}$ & $\begin{array}{l}\text { Feb. 15, } \\
1941 .\end{array}$ & $\begin{array}{l}\text { May 22, } \\
1941 .\end{array}$ & NO \\
\hline $\begin{array}{l}\text { Pellett v. Sono- } \\
\text { tone Corp. } 209\end{array}$ & $\begin{array}{l}\text { Mar. } 22,1939 \\
\text { Plaster of paris } \\
\text { left in ear after } \\
\text { making cast }\end{array}$ & $\begin{array}{l}\text { Mar. 22, } \\
1939 .\end{array}$ & $\begin{array}{l}\text { Feb. } 5 \text {, } \\
1940 .\end{array}$ & $\begin{array}{l}\text { May 10, } \\
1940 .\end{array}$ & NO \\
\hline $\begin{array}{l}\text { Pashley v. Pacific } \\
\text { Elec. Co.210 }\end{array}$ & $\begin{array}{l}\text { Sept. 3, } 1930 \\
\text { (also Sept. 3, 1932, } \\
\text { approx.), conceal- } \\
\text { ment of serious fu- } \\
\text { ture consequence } \\
\text { of injury to eye }\end{array}$ & $\begin{array}{l}\text { About } \\
\text { Sept. } 3 \text {, } \\
1932 .\end{array}$ & $\begin{array}{l}\text { Feb. 3, } \\
1943 .\end{array}$ & $\begin{array}{l}\text { June 14, } \\
1943 .\end{array}$ & NO \\
\hline
\end{tabular}

201 Huysman v. Kirsch (1936) 6 Cal. (2d) 302, 306, 57 P. (2d) 908, 910. See annotations (1931) 74 A. L. R. 1256, (1943) 144 Ibid. 209, (1944) 151 Ibid. 1027.

202 (1926) 78 Cal. App. 104, 248 P. 288, hearing den. At pp. 107, 108, 248 P. at 289, the court declared: "The original injury remains the sole cause of action, and subsequent acts which merely aggravate the damage already done, or later develop- 
An analysis of the foregoing table will show that the statutory period of one year is refused application in two situations:

1) when the period between the discovery of the nature of the wrongful act and the bringing of suit is less than one year;

(In order for the plaintiff to avail himself of this exception to the normal rule that suit must be filed within one year of the occurrence of the wrongful act, there must be substantial evidence that reasonable diligence could not have re-

ments which frequently add new elements of damage, merely attach themselves to the original cause of action and do not of themselves become independent causes of action, nor do they revive the cause of action for the original injury if the same has become barred." Huysman v. Kirsch, the ruling case in California, distinguishes and does not overrule Wetzel v. Pius; see supra note 201, at 307, 57 P. (2d) at 910.

203 (1931) 119 Cal. App. 293, 6 P. (2d) 311. This case is now overruled by Huysman v. Kirsch, $6 \mathrm{Cal}$. (2d) at 306, $57 \mathrm{P}$. (2d) at 910. It relied on Wetzel v. Pius $119 \mathrm{Cal}$. App. at 295, 6 P. (2d) at 312.

204 Supra note 201. The court in this case relies principally on Marsh $v$. Industrial Com. (1935) 217 Cal. 338, 18 P. (2d) 933, 86 A. L. R. 563. See (1936) 24 CaxTr. L. REv. 607 for a discussion of the theories on which the Huysman decision rests. Probably the decision rests mainly on the ground that the "plaintiff was in ignorance of the cause of her disability and could not with reasonable care and diligence ascertain such cause". Huysman v. Kirsch (1936) 6 Cal. (2d) 302, at 312, 57 P. (2d) 908 at 913.

205 (1938) 29 Cal. App. (2d) 699, 709, 85 P. (2d) 541, 546. Observe in the following passage the language about a "fresh breach of contract" every day the clip is not removed. Such language is clearly inconsistent with the tort theory of the applicable statute of limitations provision.

"The relation or employment in this case, according to appellant's testimony, having continued up to September, 1934, each day's failure to remove the skin clip was a fresh breach of the contract implied by law. The removal of the skin chip was a part of the operation, and in this respect the surgeon left the operation uncompleted. . . . Certainly the statute of limitations should not run against appellant's riglits during the time she was in ignorance of the cause of her disability, and could not with reasonable care and diligence ascertain such cause, and in the instant case, where, as she testified, appellant relied upon respondent's assurances, that the presence of the skin clip would not impair her health, the statute should be tolled during all the time she was under the care of respondent and consulted only with him with reference to the condition produced hy the presence of the skin clip in her body."

208 (1941) 43 Cal. App. (2d) 561, 111 P. (2d) 421, hearing den.

207 (1942) 51 Cal. App. (2d) 141, 124 P. (2d) 82, hearing den.

208 (1942) 52 Cal. App. (2d) 228, 126 P. (2d) 151. Patient here complained of rundown health for a long period. The court held that the requirement of due diligence to ascertain the cause of her condition was not violated by the seven year delay in having her jaws X-rayed. "The practice of medicine is not an exact science and it is a matter of common knowledge that physicians frequently find great difficulty in determining the cause of 'generally rundown health.' " Ibid. at 231, 126 P. (2d) at 152.

209 (1942) 55 Cal. App. (2d) 158, 130 P. (2d) 181.

210 (1944) 25 A. C. $222,231,153$ P. (2d) $325,329,330$. This case is not a malpractice case, but it involves fraudulent concealment in the physician-patient relationship, and relies on holdings in malpractice cases. 
vealed the nature of the wrongful act earlier than its actual discovery. The extremely long period, approximately ten and one-half years, between cessation of treatment and the filing of suit in Faith $v$. Erhart would appear to be a remarkably liberal recognition of this exception.)

2) when the period between the cessation of treatment and the bringing of suit is less than one year. ${ }^{211}$ (In this situation the facts must compel the inference that the initial wrongful act is contimuing or that there was justifiable reliance on the physician's representations as to his treatment.)

$221 \Lambda$ stronger case exists, of course, if the suit is filed within one year of both the cessation of treatment and the discovery of the wrongful act, although more than one year after the occurrence of the wrongful act. See Huysman v. Kirsch, supra note 201. 